\title{
參加世界科學工作者協會二屆大會的觀感
}

\section{谷超 豪}

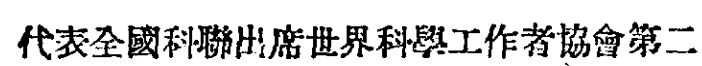
届代表大會的代卦團，是由梁茠、茅以是、曹日 目、張是紹、谷超豪等五人組成。包含了不闰的學 科，不同的地區，不同的年袺的利學工作者。在 3 月

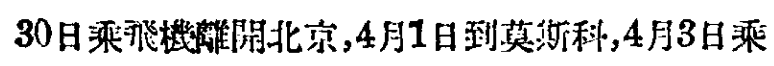
推飛抵捷宗布拉格。大會原定地址是巴黎，我們就 在唗克中請入法境的签證,但足不僅我們，而且其 他人民氏主國家的代表，都被法國反趿政府拒絕 筑證，因此大會被迫分雨地舉行。在 4 月14日间果

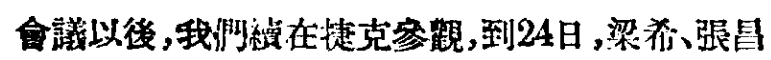

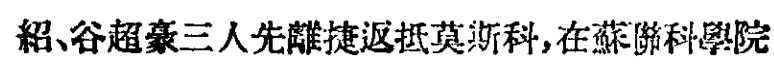

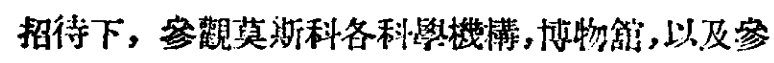
加五一節的大舆。到5月8日，茅以景、曹日星也抵

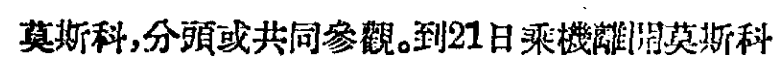
回國，在旅涂以及國外共55日，得到很好的機會

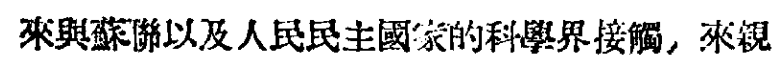

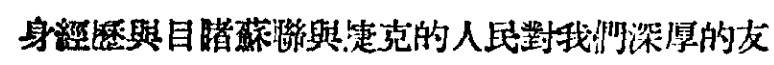

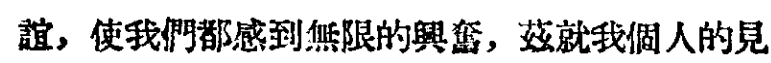
閒,作一简略的報䢍:

\section{一 光榮艘於祖圈}

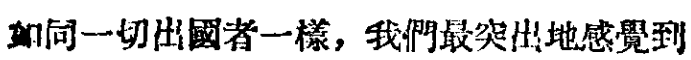
的便是，我們的祖國; 在今天的世界上亭有慥大的 光榮，世界上進步的人民，正以兄弟般的友誼非常 親切熱烈地對待着我們。

我門是科學工作者的代表團，因此所接触倒

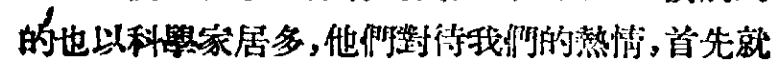

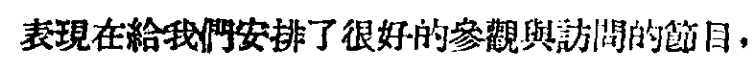
凡是我門所要求去的地方，凡是我們所希堂有的

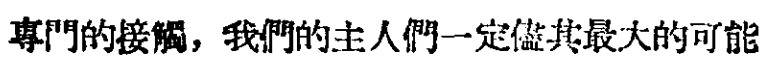

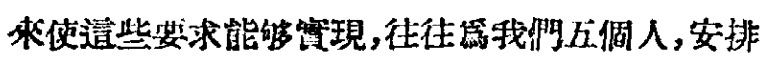

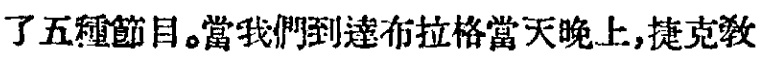
角部就泥人來然料我們，第二天，作感科學工作計
新機構的“科學兵技街發展中心研究局”的负资人

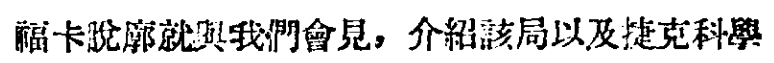

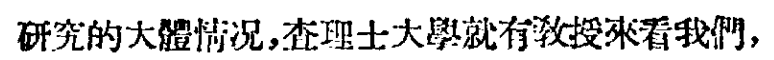

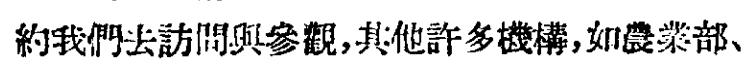

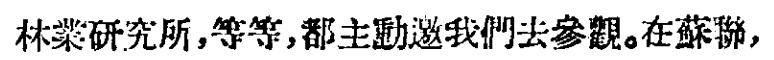

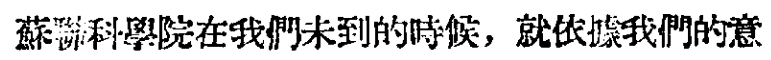

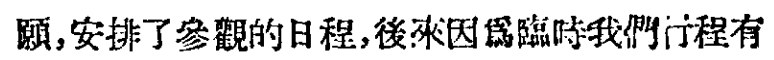
一些變化, 大策都知湴, 蘇篎的一切工作都按一定

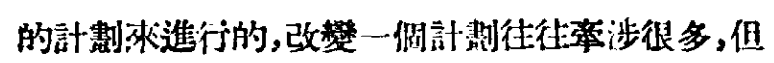

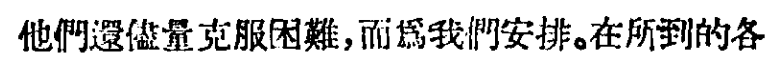

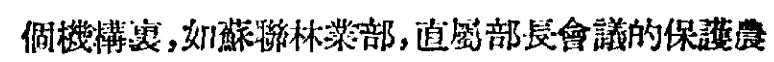

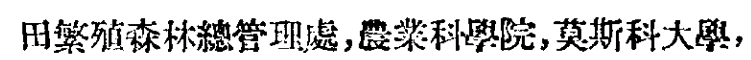

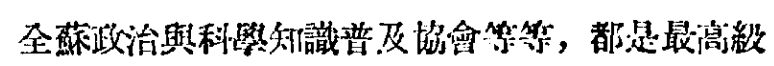

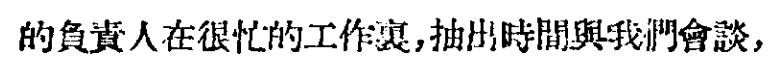

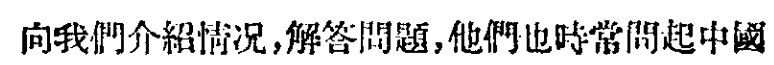

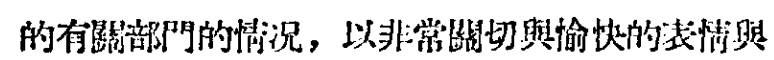

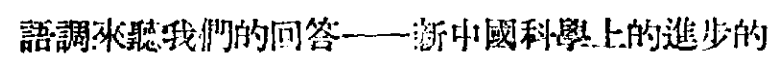

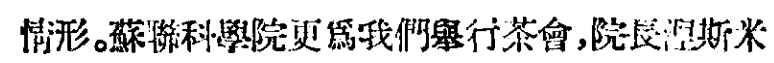

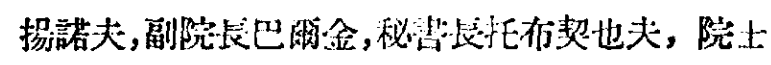

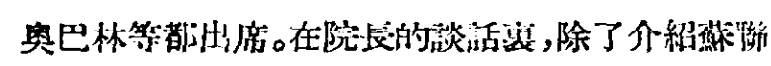

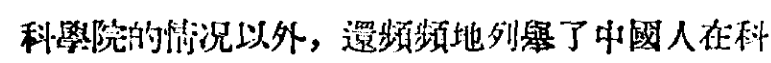

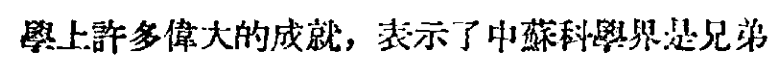

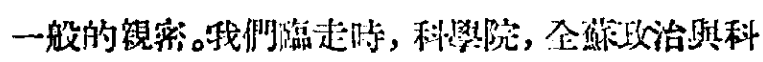

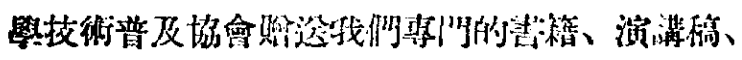

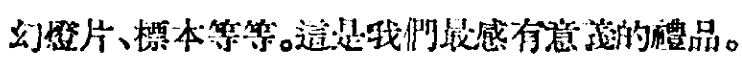

使㖅們感到光策的場酎太多了，在徒况，世界

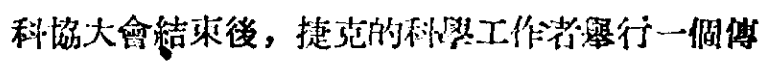

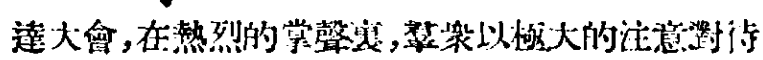

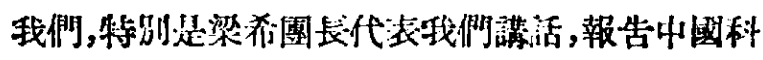

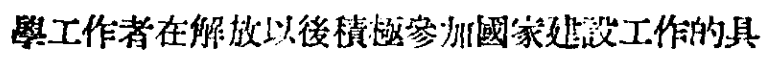

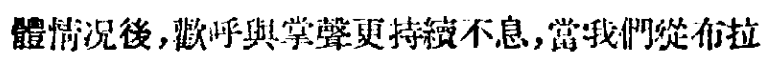

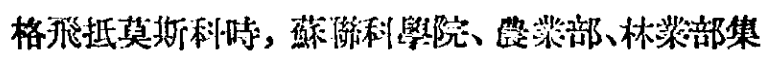

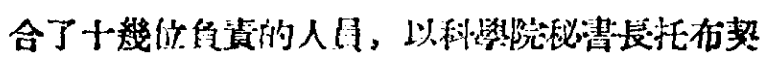




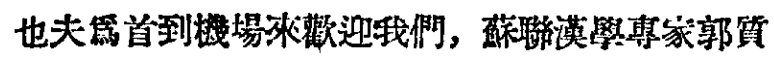
生特棣担任翻譯，我們感到特别光策的是在 4 月 28

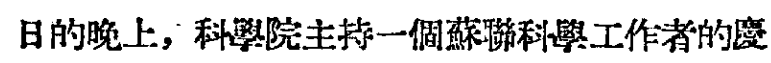

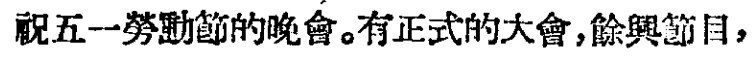
(都是栖侍名的演員參为演出)與舞會。我們不僅 被邀寥加, 而且在大會洔,被邀坐在主席合的流排 。在主席台上,都是集聯利學界的颃袖與在科學最 有成就的人物幻院長湟斯米掦諾夫，院士勒柏辛

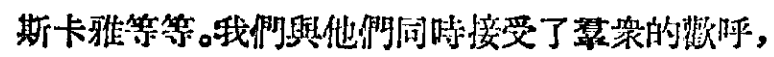

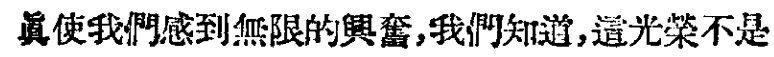
瓷於我僻個人的, 而且感於所有激中國的科學工

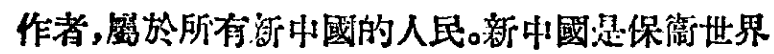
和平的重要力量, 是一切進步人士都衰心承認亚

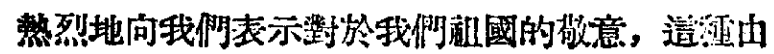

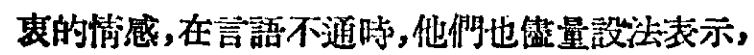

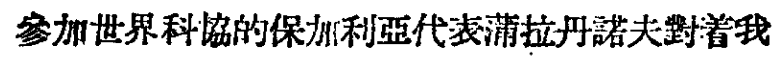

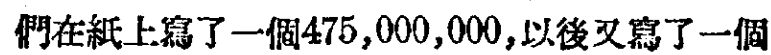
$6,000,000$ 把它为起來成筬 $481,000,000$, 他的意 思是中國有四檍七千五百萬人口，保为利亞六百 萬人口，現在逜记億八千一百萬人團結在一起了， 他寫完之後，我們馬上就彼此會意了，於是熱烈地 握着手。

如果說科㙾家們的熱情是以比較深沉的方式

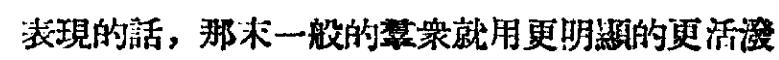

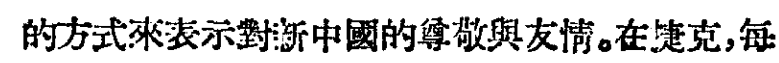

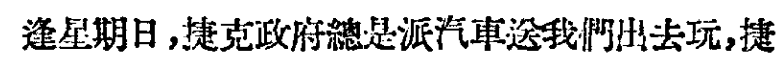
克的星期日是紫張的，在鄉村中也到處可以看到

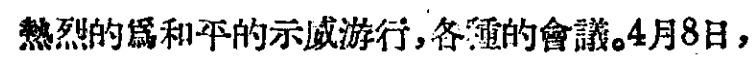
我們一到馬里安斯克㗪泉洔, 當地的青年正在舆 行保簿和本大會,馬上就派人棣邀請我們,到大會

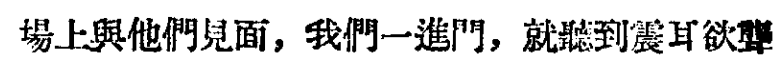
的“斯大林! 哥德龩㕣德! 毛澤東!”的萑呼,在主庹 對我們作简單的介紹，我們政了簡短的视詞 以

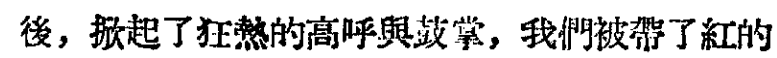
領結離䦎會場，在郱倜地方的黨政负資问志招待

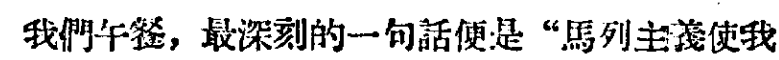

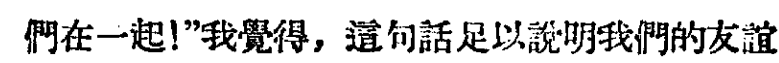

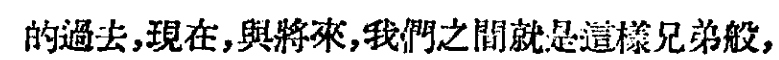
同志般地相處。4月15日，我門到著名的皮鞋䯘所

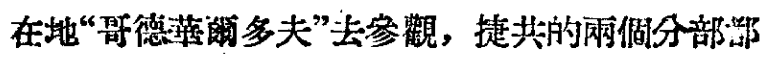

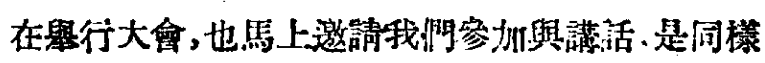
地熱情與鹤樂, 而且, 在我們出了會場之後, 有一

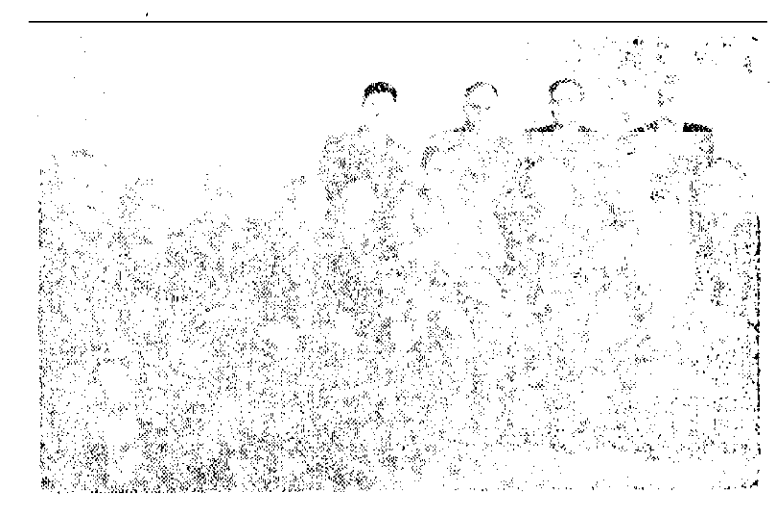

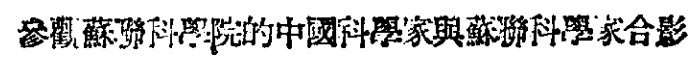
從右至右坐者:

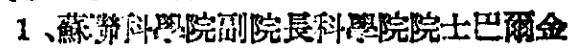

2 、梁希数授

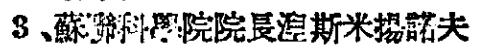

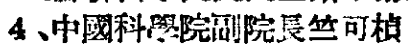

5、北方交涌大隆校骎茅以鼠教骎

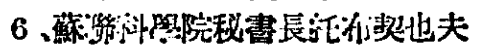

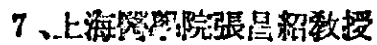

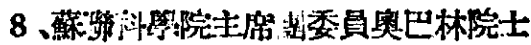

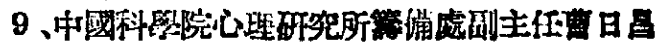

立者:

10、浙江大界助整谷超豪

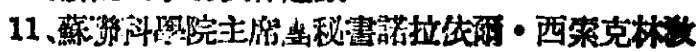
授

12.世維䨕・金閉爾致授

13、尼可拉依・司曼勈諾夫教授

個分部做了决㦈，說“捷克踓然是小國，但必須坮

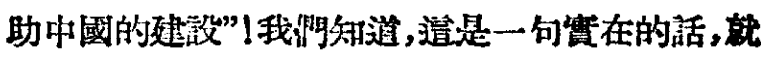
在那時的一週以前，當地就有製革方面的素家㽖 身來北京，我個人，更受到捷克青年辝多熱情的接 待，一侽地方的青年組織的鱼责人，祭握了我的 手，“篇了提克與中國的青年的图結，前進!”流 露了青年人特有的熱情，“科學與技街發展研究中 心局”的青年組織，還特地召開會議，歡迎我造珠 自中國的青年。在渵聯，五一節紅場上的情最更

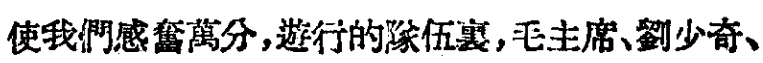
周恩來、朱總司令的像在花束與自由的人所組成

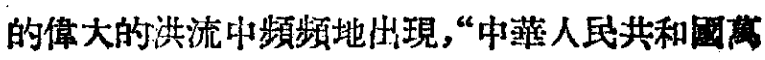

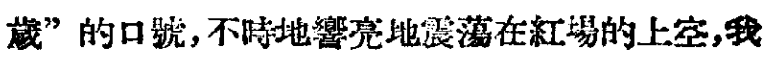
國有很多代表在觀的豊台上，除伍在中國代表面前 又掀起了一泍㴶呼鼓掌的高潮, 形成了偉大的籸 坦上特刟引人注意的一角, 看到了國際友人如此

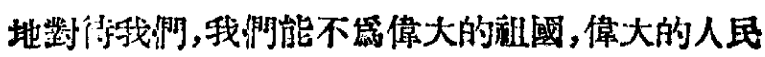
感到光策與野缴嗎!

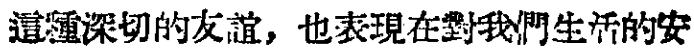

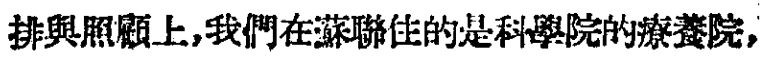




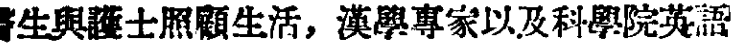

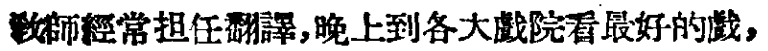
盛攸之隆，是難以形宾。

\section{二'局和平而国結}

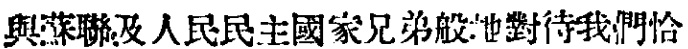

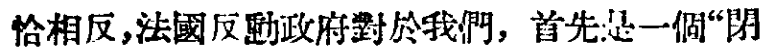
阴䔄”。世界科協原定在巴黎於4月10日阔始陆會， 我們到了布拉格以後, 就通過了捷克外交部, 向法

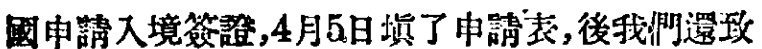
䉓世界科協在巴黎的眑絡人畢加，請他設法向法

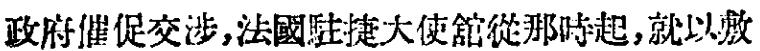
行的態度對付我們，一道拖到9日下午，最後的定 的時閒，還是不給答覆，到10日上午，才回答說，法 國政拊决定拒稆給予我們签證，而且捷克等人民 民主國家的代表,也被拒絕入境。

法國反趿政府的這猠措施，並不是偶然的,只 要看西殹資本主涹國家的科學家的處境, 就何以 明白了，一位西歐的科祭家，就想大韾次呼：“現在 資本主義國家內科學家所受是迫，已完全與1935

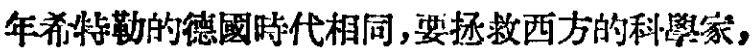
現在就望做“美帝及供其驅使的常國主晕國 “家的

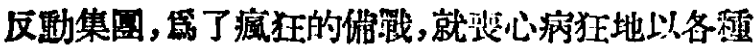

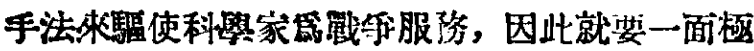

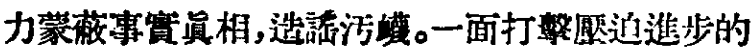
科學家，以及運用電種手段，制空科學家的自由， 限制科學文化在國際上的交流。與此同時的，却是 世界保部和平運動的高浱之中，如會長的里奧 居里所指出的,已使科學在注會蔓的使命，逐漸地

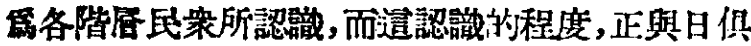
增。科學工作者自身的資任感，也日谷明碓，因之 世界科協的必姴與其力最也逐濑学科學工作者所

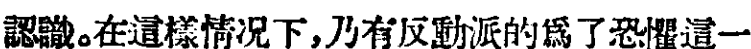
股進步的和平力量的發展而企圆來分化例弱它，

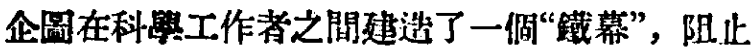
我閒把人民做了主人的國家，科學逢勃地在篇國 家建設要人民福利服䧄目標下的閒展情况，告訴 世界上所有科祭工作者以及人民。法國反陲政府 拒絕給我門以及其他人民民主國家的代表以签

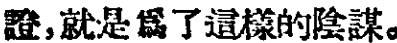

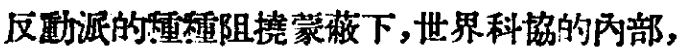
也因此有了一些困難，因篬世界科協也遭受到一

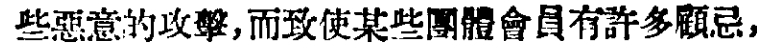
英國的科協，受到了扒入所謂“世界自由工聯”的

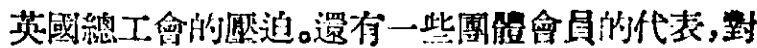

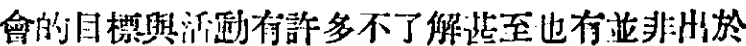

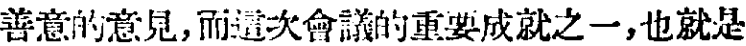

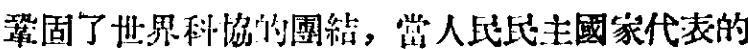
簽證遭到了拒絕時，已是巴黎大會所决定的開大 會的洔候了,在巴黎大會開幕洔,就正碓地决定了

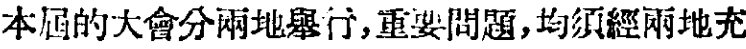

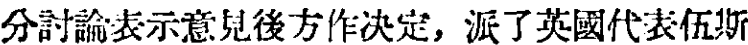

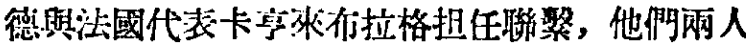
在11日中午到達了竹拉格，有拉格的大會随即在

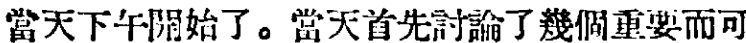
能有不同意罢的僮案，如卧於世界科協與世界工

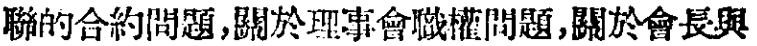
理事的提名問題等:等，我門一面討墖一面與巴黎 大會用長途笔活進门聯㢣, 對於造些問題, 人民 民主國家的代表以及西缼科學家的進步組織，保 了照倠會的團絬與装干會员團體的若干困難, 在 堅持世界科協的會章與㶳章的原则之下，作了維 多譩步，捉出一些修证的意見，這些意見，也得到 巴黎方面的同意，而終於使兩個大會,在和協的空 氣下，解决了許多問題，而肇固了整倜世界科協的

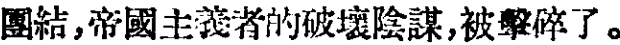

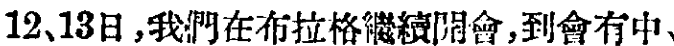

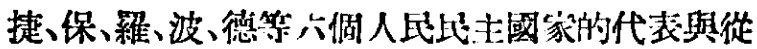
巴黎來的英、法网成的代表，大會在非常繦洽的氣 氛中進行，主人提克代表的招待非常邀到，各代表

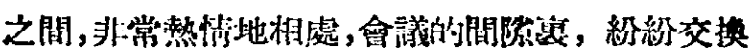
䣓物，徽章，倜别地接触，充分地婊現了一一我們 是一家人。會議就世界科協的雜誌“科學與人類”

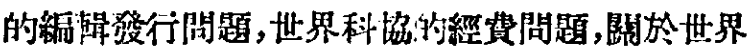
科學工作者的增加接觸與科學工作成果的不相交 流問題,都作了悉怚的研究，事貲證明了，人民比 主國家的科學工作者，願意而有能力支持世界科 協，捷克負筫了會刊的大部份工作與經貿，中國本 來是壮不起會資的會員，在去年激了二百鎊會筫 而使理事會的浽留困難得到了整時的澥除，保㧈 利亞也募集了相党的捐款,這與西歐國家的科㙝, 却因會具䆩際收入的減少，而所能負担的經洲能 力也日谷減少,在英法等國會刊的發行，梁受到私

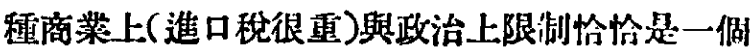


解明的璟比。人民地主國家,準借在名䶼地方建立 科學工作者避暑的休奉任所, 歡迎國際科學家前 往避暑，箸加國際利學工作者接䚪，也恰恰與奏國

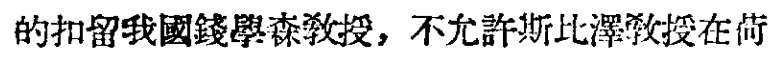

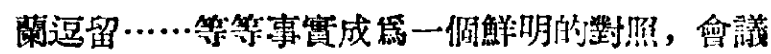

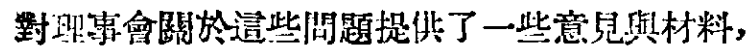

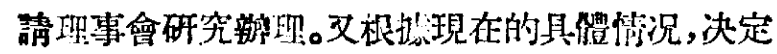

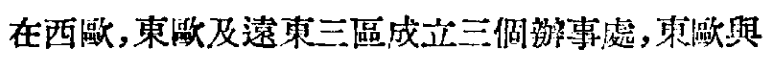
遠東的中心分别在价拉格與北京，正如總朝事克

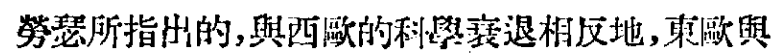
中國的科學工作，在解放後都已有了長足的進步， 西歐在科學上“唯我罱每”的洔代是過去了!

布拉格會議的一㑬重大成就便是鮮朋地樹立

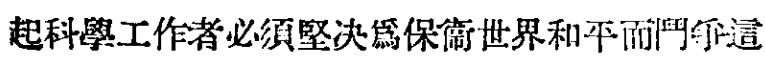

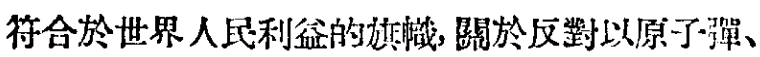
巠彈、細菌武器從事毁威人類的戰的以及主张國 際監督管理, 英國科協有一個建議, 在价拉格作了 一些修改以後,兩地一致地通過了，价拉格大會到

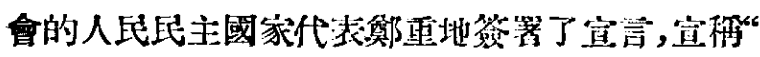
在這個閏争的决定性時機，我門科學工作者淮影 和所有的進步力量在一起,在各自的國家內,積極 地展開保衞和平的閏手!”會議决定,將在1951年99 月間,召集國際科學工作者大會, 更塂泛地團結全 世界的利學工作者，以保障企人類幸福的將䧒。这

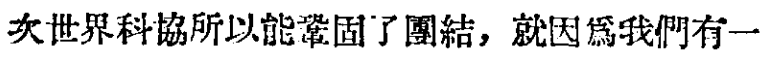
個共同的準则,這就是大會的會章與畫意,它規定

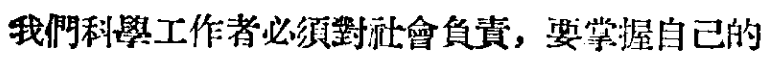
工作成果的使用，使其海湢人類而不是毁隇人類, 所以在13日會議結束洔，捷克與中國的代表在大

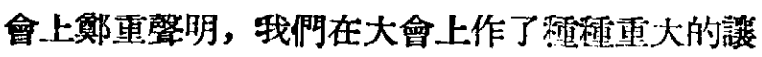

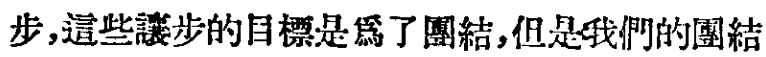
並不是無原则的, 而是第了世界的科學工作者,能

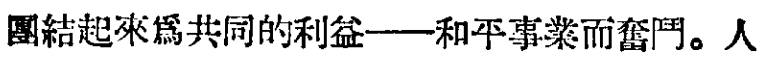
民民主國家的科學家，因其本國是舜好和平的,和 平給他們工作以傿限的前途, 自然是盡力争取和 本，而資本主義國家的科學家，因其反趿政府的俏 戰政策，直接威叒了他們的生活，限刜了他們的工 作, 所以絕大多數也迫切需要和平。今後科學界

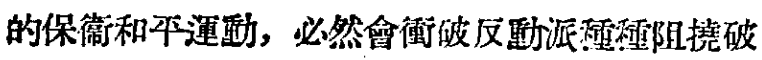

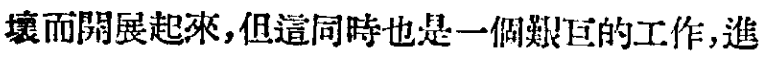
步的科學工作者們所負的資任是非常禹大的。我 們這一次寗加會議,也深切地感到，今天中國的科
學工作在這一方面的作用，例如逼次會議之所以 能分兩地開會,而因之得到現有的一些成就, 是和 䍃中國的代表已經到達布拉格, 中國的科聯是世

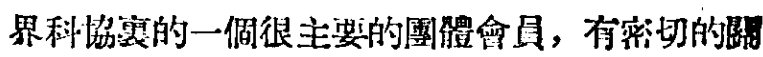

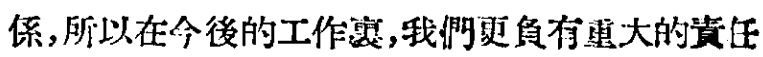
來推坵這一连䣦。

\section{三 向先進的科學習}

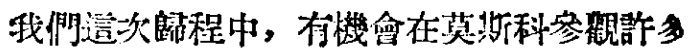

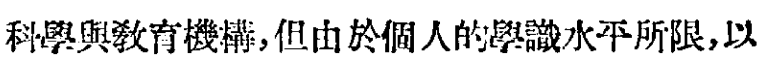

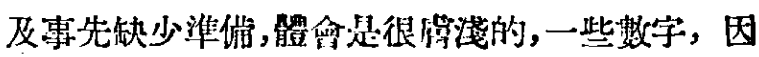

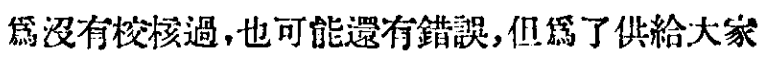

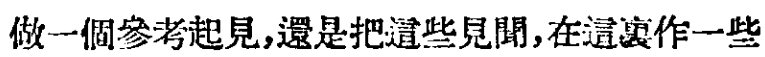
的報薏。

使我首先感到的是 葆聯利學的進步 和 传越 性, 這程進步性表現在它能够很好地第征服自然 改善人類的生活而服杼, 在蕉聯, 正在進行着的著

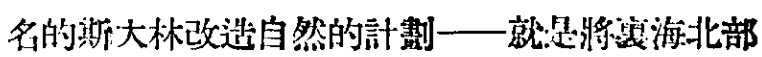

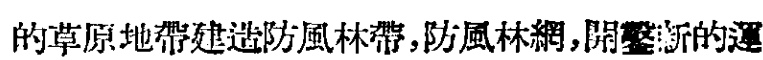
河，起築隌大的水電站等。這個計割的偉大只管看 它將湕䢤近六百萬公顷面棈的人造林就可得而

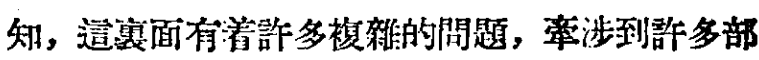

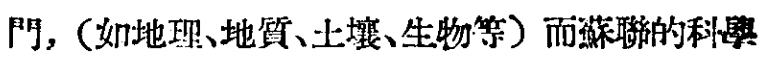
界,能光策地負担起研究這祭問題的任務, 而獲得 優秀的成果，(例如李森科的“籍式播溲造林法”就 有很大的成功)據說因各方面的烃力,䧟個自 1949 年阙始猜期15年完成的計劃，其植林部份可期望 在今後五、六年成功。在森林技術學院，有一個研 究題目䍃如何選擇種植在城市要的作物，其浀求

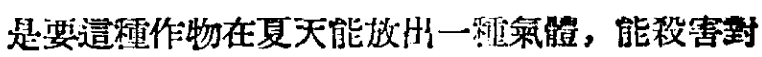
人類有害的細菌。全蘇政治與科學知清普及協會

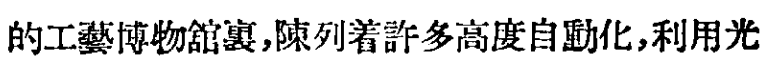
電反胦，管理控制都非常简便而能發挥高度效能

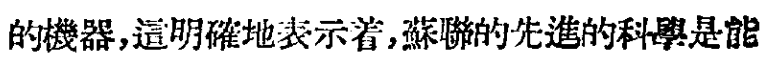
篇改善人的生活條件，焱忬條件，能够光榮地共 座主㼁建設作具體而切實的努力。

蔡聯科學的先進性也可以從其大批地培童人 才壝一點來看到，三十年來，單在森林技衍方面， 就培蒼了二十萬人庄右，最近二年中，特有六千大

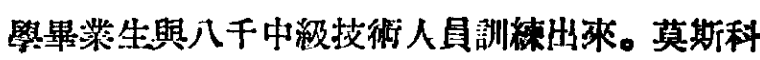

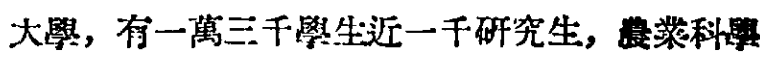
院,有三千五百學生(一坐堂女生)及四百研究生, 


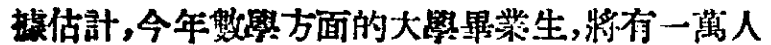

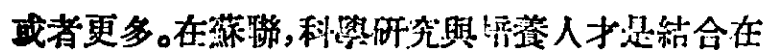

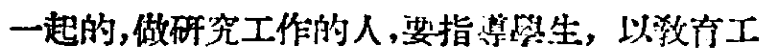

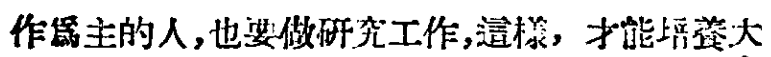
量而文有研究工作能力的科學工作的有生打量 來。

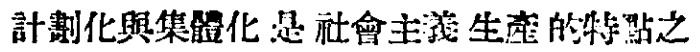
一,造也表現在科學研究工作上,各個部䢹, 都有 其研究工作的計割, 而造渐計劃的擬訂,首先在於

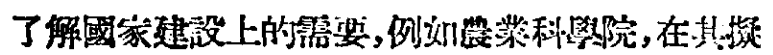
訂計都之前, 各部門的主持的数授先到贯新部去 了解圂家的露望，所訂定的計㓶草案經過了倠關 的行政機構,補充,修正,批准以後(這樣更可配合

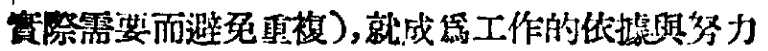
目標, 通些計劃裹具膘地包含了各個研究室以至 於各倜倜人的分工（各倜㑑人也還可以進行計剩 以外的研究), 往往, 䚺多建设上的問題贸很偉大

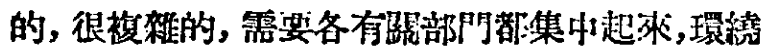
一個問題, 作配合的研究, 例刘前述的改造自然的

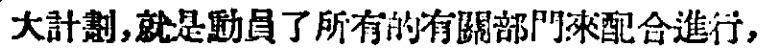
有一倜防風林帶的調查圈, 就在森林研究所主持 下，有地賀、野物、微生物、土壤、經濟、地理等多方 面的研究所共同寥玑。基本的耽詥科學的研究工

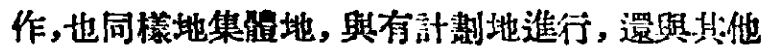
科目保持緊堔的聯薮。數學的研究工作, 是和水力 围、梳計學、物理學以及其他許多工程技術部門作

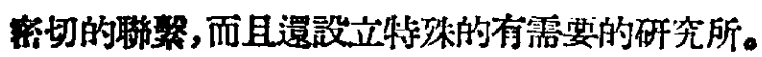

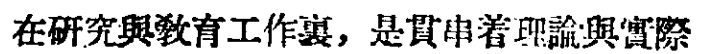
一致的精神，農籍科學院的祭生，有三分之一的學 習時間在作望習，起初二年，在學校的農場襄，從

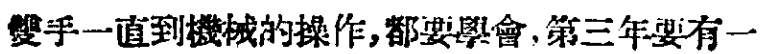

段咕間，由数授帶到集能震場工作，第四年就以猩

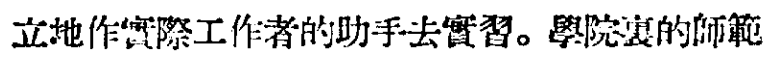

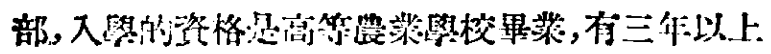

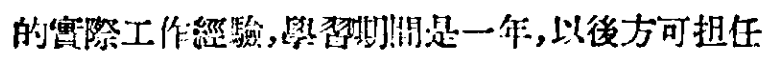

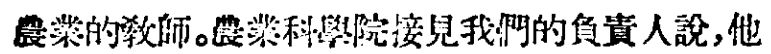

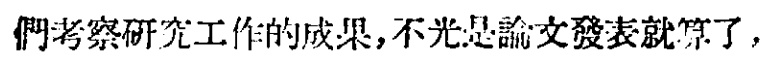

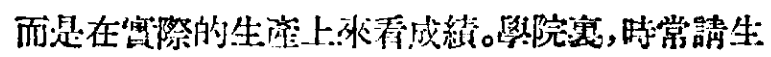

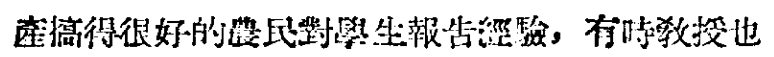

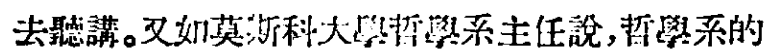

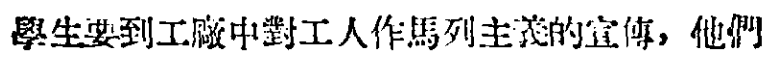
所培養的不僅是口須上耐足霓際上的馬列主成 者。

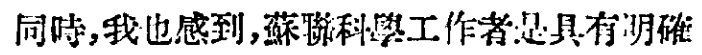

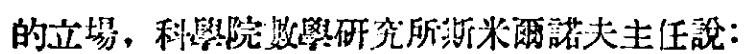

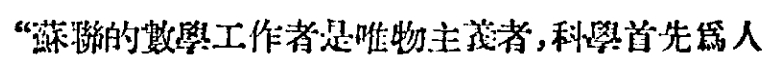

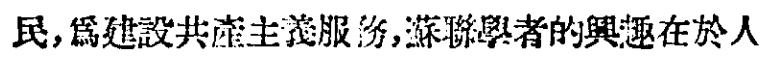

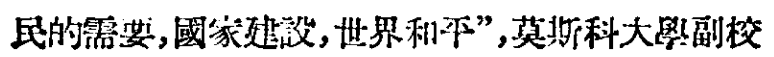

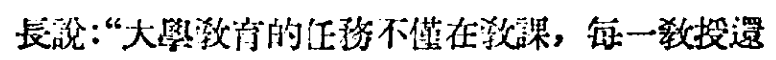

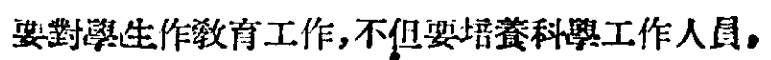

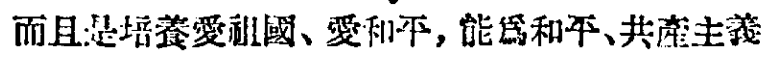

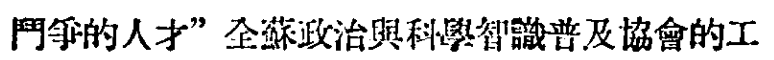

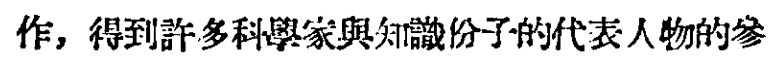

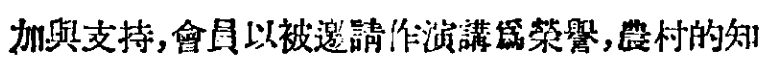

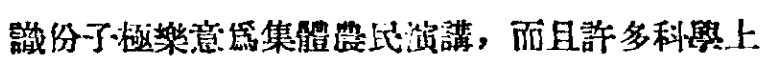
的演講, 講前經過了討諭, 講後通過批游而改淮, 以求在學街上與思想上水平的提高。

在唗克，我門也看到了迨漛的方向，破究工作

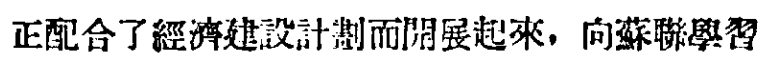

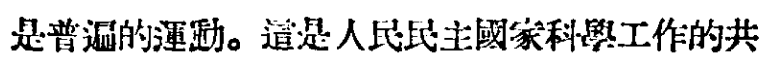
同的精神，譲我們以加快的步伐努力麻進、巴

\section{德國駐華代表團訪問中國科學院}

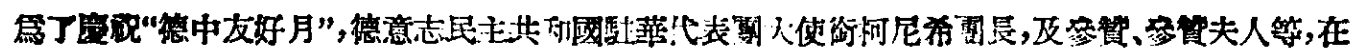

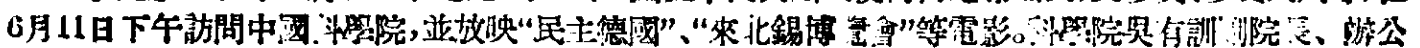

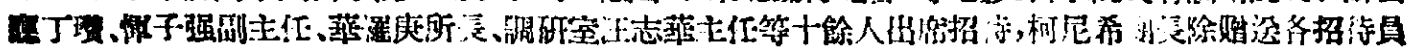

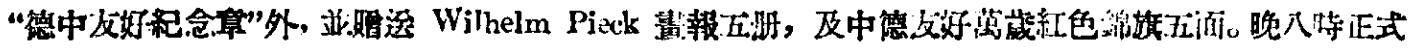

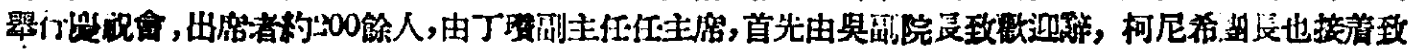

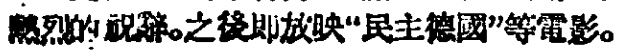

(㨴) 